\title{
Sporda Sosyal Alanlar Makalelerinin Araştırma Yaklaşımlarının İncelenmesi
}

\section{Methodological Analysis of Articles in Social Discipline of Sports}

\author{
${ }^{1}$ Safter ELMAS \\ ${ }^{2}$ Aydan GÖZMEN ELMAS \\ ${ }^{1} \mathrm{~F}$. Hülya AŞÇఁI
}

${ }^{1}$ Marmara Üniversitesi, Spor Bilimleri Fakültesi, Sporda Psiko-Sosyal Alanlar A.B.D.

${ }^{2}$ Marmara Üniversitesi, Spor Bilimleri Fakültesi, Spor Yönetim Bilimleri A.B.D.

\section{Yazışma Adresi \\ Corresponding Address:}

Araştırma Görevlisi Safter ELMAS ORCID: 0000-0002-8519-163X

Marmara Üniversitesi Spor Bilimleri Fakültesi, Anadoluhisarı Yerleşkesi, İstanbul

E-posta: safter.elmas@gmail.com

Geliş Tarihi (Received): 28.12.2017 Kabul Tarihi (Accepted): 23.05.2019

\section{öz}

Bu çalışmada spor bilimleri dergilerindeki sporda sosyal alanlar makalelerinin araştırma yaklaşımlarının incelenmesi amaçlanmıştır. Makalelerin araştırma konularında, yöntemlerinde, desenlerinde, veri toplama tekniklerinde ve araştırma alanlarında hangi yaklaşımların benimsendiği belirlenmeye çalışılmıştır. Araştırmada nitel araştırma tekniklerinden doküman inceleme tekniği seçilmiştir. Araştırma kapsamında spor bilimleri alanında en az on yıldır süreli akademik yayın yapan üç dergi incelenmiştir. 1990-2016 tarihleri arasında, sporda sosyal alanlarda yayınlanmış 400 makale, araştırma yöntemi, araştırma deseni, veri toplama teknikleri ve araştırma konuları başlıkları çerçevesinde sınıflandırılmış; 1990-1999, 2000-2009 ve 2010-2016 olmak üzere üç tarihsel dönem çerçevesinde incelenmiştir. Kategorize edilen veriler, içerik analizi ve betimleyici istatistik kullanılarak analiz edilmiştir. Analiz sonuçlarına göre, 400 makalenin $\% 78^{\prime}$ i nicel, $\% 13,2$ 'si nitel araştırma yöntemi ile; \%8,8'i derleme niteliğinde gerçekleştirilmiştir. Nicel araştırma yöntemleriyle gerçekleştirilen çalışmalarda ilişkisel tarama \%68,6 ile en çok tasarlanan araştırma deseni iken, çalışmaların \%78,2'inde veri toplama aracı olarak ölçek kullanılmıştır. 400 makalenin $\% 55,5^{\prime}$ i spor psikolojisi; \%20,8'i spor yönetimi; \%13,5'i spor sosyolojisi ve $\% 6,3^{\prime}$ ü rekreasyon alanlarında yayımlanmıştır. Araştırmanın sonuçları, baskın metodolojik yaklaşımın nicel yöntem olduğunu, araştırmaların sıklıkla ilişkisel tarama desenleri çerçevesinde ve ölçek formları ile planlandığını, nitel araştırma yöntemlerine ait desenlerin oldukça geri planda olduğunu ve sporda sosyal alanlarda en çok çalışmanın spor psikolojisi alanında yapıldığını göstermektedir.

Anahtar Kelimeler: Sporda sosyal alanlar, Paradigma, Nicel, Nitel

\section{ABSTRACT}

This study was aimed to examine the methodological approaches of the articles in the social aspects of sports in the journals of sport sciences. In the research methods, design, data collection tools and sub-discipline of the articles were investigated. Document analysis was used in the study. Three journals, which have been publishing articles at least ten years, in the field of sport sciences have been examined. Between 1990 and 2016, 400 articles in the social field of sports sciences were classified based on subject, research methods, design, data collection tools and research areas. These articles were examined in three historical periods; 1990- 1999, 2000-2009 and 20102016. The classified data was analyzed by using content and descriptive analysis. The findings showed that $78 \%$ of the 400 articles were quantitative, $13,2 \%$ were qualitative research method, and $8,8 \%$ of the articles were review. In studies conducted with quantitative research methods, correlational design was mostly used research design with $68,6 \%$, in $78,2 \%$ of the studies, scale was used as data collection tool. The findings showed that articles were frequently conducted in different subdisciplines such as sport psychology $(55,5 \%)$, sport management $(20,8 \%)$, sport sociology $(13,5 \%)$ and recreation $(6,3 \%)$. The results indicated that quantitative methodology is dominant in the social disciplines of sport. Moreover, researches are frequently planned with correlational design by using scales as data collection tools. Qualitative method designs remain in the background and sports psychology is most studying sub discipline of social field of sports sciences.

Key Words: Social areas in sport, Paradigm, Quantitative, Qualitative 


\section{GíRiş}

Akademik araştırmaların ve yayınların ortaya koymaya çalıştığı problemlerin planlanmasında en temel belirleyici bilimsel paradigmalardır. Bilimsel amaç ve işlev, hangi yöntemlerin ne şekilde kullanılması gerektiği, araştırma dizaynı, araştırmanın bilimselliği ve araştırma konusu ile ilgili konularda araştırmacıya, özellikle araştırmanın felsefesi noktasında yön veren, benimsenen bilimsel paradigmalardır (Kuhn, 2008; Dikeçligil, 2010, s. 54).

Psikoloji başta olmak üzere diğer sosyal bilim alanlarında sayısallaştırma, nicelleştirme ve somutlaştırma hegemonyasının kökleri Batı Aydınlanmasına kadar uzanmaktadır (Cosgrove ve McHugh, 2008). Endüstriyelleşmenin bir sonucu olarak teknolojinin kültürel olarak benimsenmesi, sosyal bilimler alanında da pozitivist-niceliksel yöntemin hakimiyet oluşturmasını beraberinde getirmiştir (Craig, Amernic ve Tourish, 2014). Pozitivist paradigmaya dayanan nicel yöntemin sosyal alanlarda kabul görmesiyle, dönemin araştırmacıları fenomenden/problemden çok yönteme odaklanmış; bu odaklanma, araştırmacıların rahatsız edici ve cevaplanmamış soruların olduğu fenomenlerden kaçınmalarına imkan sağlamıştır (McDonald ve Birrell, 1999, O’neill, 2002). Niceliksel yöntemin sosyal bilimler alanında benimsenmesi ve deneylerin, ölçümlerin, değerlendirmelerin tek tip yöntembilimin bir sonucu olması, bir yandan araştırmacılara uzmanlaşmada ve alanın diğer çalışanları ile iletişimi kolaylaştırmada hatırı sayılır imkanlar sunarken diğer yandan sosyal bilimlerin epistemolojik kaynaklarının ve öznelerin sosyal deneyimlerinin belli bir sınırlılık içerisinde ortaya çıkarılmasına sebebiyet vermiştir (Cosgrove, Wheeler ve Kosterina, 2015).

Sosyal bilimlerin bir fenomeni (olgu/özne) ele alışında, değerlendirmesinde ve onun boyutlarını ortaya koymada epistemolojik kaynaklarının sınırlılıklarını genişletebilmesi için, öncelikle 'sosyal' olanı ve sosyal alandaki dinamiklerin (tarihsel, toplumsal, kültürel vb.) belirleyiciliğini (bağlamı) gerçekliğe ulaşmada öncelikli kılması gerekmektedir (Gill, 2011; Kümbetoğlu, 2005). Sosyal alanda gerçekleşen bir durum sadece ölçülebilir, genellenebilir ve tanımlamacı bir perspektifle incelenmemeli; özneler, fenomenler ve yaşantılar derinlemesine, anlamacı ve yorumlamacı bir bakışla ortaya konmalıdır (Koca, 2017).

Fenomenolojik psikolojinin kurucusu olarak bilinen Edmond Husserl da sosyal gerçeklik ve epistemolojik duruşa dair, 1900'lü yılların başlarında hem psikolojinin hem diğer sosyal bilim alanlarının yaşadığı bu epistemolojik krizi tarif ederken: "Uygun bir bilim felsefesi temeli olmadan sosyal (yaşayan) deneyimleri sanki ölçülebilen bir 'şey' gibi ele almanın tehlikeli bir 'doğallaştırma' hatasını işlemeye sebebiyet verdiğini”' belirtmiştir (Cosgrove ve ark., 2015, s. 17'de belirtildiği gibi). Husserl'in ardılları da öznelerin nesnelleştirildiği ve bilgiye ulaşmanın tek geçerli rotasının doğal, pozitivist, deneyci model olduğu yaklaşımının, insan deneyimlerinin sosyo-politik ve sosyo-kültürel temelli kıymetinin anlaşılamamasında asıl problem olduğunu dile getirmiştir (Giorgi, 2012; Applebaum, 2012; Cosgrove ve McHugh, 2008). Fenomenolojik yaklaşımın dünyada 1950'lerden itibaren özellikle psikoloji alanının tek tip yöntem benimseyişine eleştirileri bir öncü hareket gibi olmuştur. Diğer sosyal bilim alanlarında da yapısalcı, inşacı, eleştirel ve feminist yaklaşımların bilimsel gerçekliğe dair ortaya koyduğu alternatif yöntemler, sosyal bilimler alanında özellikle 20. yüzyllın ikinci yarısından itibaren doğru bilgiye nasıl ulaşılabileceği üzerine önemli tartışmalar yaşanmasını sağlamıştır (Morawski, 2011; Fryer ve Fox, 2015; Mattos, 2015).

Sosyal bilimlerde olduğu gibi spor bilimlerinin sosyal alanlarında da paradigmaya dair araştırmalar, değerlendirmeler, sorgulamalar ve eleştiriler 1980'ler itibariyle kendisini göstermiştir (Martens, 1987; McDonald ve Birrell, 1999; Giacobbi, Poczwardowski ve Hager, 2005). Uluslararası sporda sosyal alanlarda araştırma makalelerinin paradigma yaklaşımlarını incelemek amacıyla farklı çalışmalar yürütülmüştür. Örneğin, spor psikolojisi alanında yayın yapan üç derginin incelendiği çalışmada Culver, Gilbert ve Sparkes, (2012) 2000-2009 arası dönemde yayımlanan 631 makalenin 
\%71'inin pozitivist-nicel araştırma yöntemleri ile gerçekleştirildiğini ortaya koymuştur. Bunun yanı sıra, spor yönetimi alanında gerçekleştirilen çalışmada International Journal of Sport Management dergisinin 2000-2008 yılları arasında yayımladığı 203 makalede \%71,9 oranında pozitivist bir eğilimin olduğu belirlenmiştir (Quarterman ve ark., 2010). Sport Marketing Quarterly dergisinde spor pazarlaması ile ilgili yapılan çalışmada ise 1992-2014 yılları arasında yayımlanan 451 makalenin \%54,8'inin pozitivist yaklaşımla gerçekleştirildiği ifade edilmiştir (Abeza ve ark., 2015). Bununla birlikte, Social Science Citation Index içinde yer alan ve 1993-2008 yıllarını kapsayan sürede incelenen 7655 makalede modelleme, geçerlik-güvenirlik, ölçek geliştirme gibi niceliksel yöntem araştırmalarının popüler olarak çalışıldığı ortaya çıkarılmıştır (Gau, 2013). Spor bilimleri alanındaki uluslararası beş akademik dergide 2010-2015 yılları arasında yayınlanan toplam 542 spor sosyolojisi makalesinde ise diğer sporda sosyal alanlardan farklı olarak \%86,2 oranında yorumlamacı-nitel yaklaşımla araştırmalar gerçekleştirilmiştir (Koca, 2017).

Türkiye'de ise spor bilimleri alanında, akademik makalelerde kullanılan araştırma yöntemlerini inceleyen çalışmalar oldukça sınırlıdır. Spor Bilimleri Derneği’nin bünyesinde 2006-2014 yılları arasında gerçekleştirilen kongrelerdeki bildirilerin incelendiği çalışmada 1624 bildirinin \%89 oranında nicel yöntemle gerçekleştirildiği, psiko-sosyal alanlar bildirilerinin de tüm bildirilerin \%41,8'ini (679) kapsadığ tespit edilmiştir (Bal ve Pepe, 2016). Elmas, Açıkgöz ve Aş̧ı'nın (2018) sporda sosyal alanlarda yazılmış tezlerin paradigma yaklaşımını (araştırma konusu, yöntemi, deseni, veri toplama araçları vb. kategorilerle) irdeledikleri çalışmada, 2000-2015 yılları arasında yayımlanan 1023 lisansüstü tezde $\% 83,4$ oranıyla pozitivist-nicel yaklaşımın baskın olduğu ortaya konmuştur.

Türkiye'de spor bilimlerinin sporda sosyal alanlarında bildiri ve tezlerde mevcut bir pozitivist-nicel araştırma geleneğinin baskın olduğu yukarıdaki çalışmalardan da anlaşılmaktadır. Bu çalışmada ise akademik makalelerin paradigma yaklaşımlarının incelenmesi amaçlanmıştır. Sporda sosyal alanlardaki uluslararası makalelerde (spor sosyolojisi hariç) pozitivist paradigmadan pozitivist olmayan paradigmalara dönüşümün olmadığı fakat yavaş da olsa yönelimin olduğu bir süreçte, ulusal düzeyde alandaki mevcut makalelerin paradigma yaklaşımlarında nasıl bir aşamada olduğunu ortaya koymak da çalışmada amaçlanmıştır. Belirtilen amaçlar doğrultusunda, 1990 ile 2016 yılları arasında psikoloji, yönetim, sosyoloji, rekreasyon, tarih, felsefe gibi sporda sosyal alanlarda (Maguire, 2013) gerçekleştirilmiş; bu alanlar içinde değerlendirilebilecek makaleler, paradigma yaklaşımları kapsamında incelenmek üzere seçilmiştir. Çalışmanın bulguları ışığında, makalelerde kullanılan araştırma yöntemlerinin genel durumunu ortaya koymak ve bu durumu paradigma üzerinden tartışmak hedeflenmiştir.

\section{YÖNTEM}

Araştırma kapsamındaki makaleler, doküman inceleme ve kategorik içerik analizi yoluyla betimleyici ve yorumlayıcı nitelikte bir yöntem ile incelenmiştir. Betimleyici araştırmalar, olayların özelliklerini ve sıklıklarını belirlemek amacında olan durum saptayıcı araştırmalardır ve kategorik içerik analizi ile uygulanırken önemli avantajlardan biri amaca uygun ayırımları kategorize etme, incelenen belgeler üzerinde araştırma amacına uygun ama akla önceden gelmemiş olan bir takım durumları gözlemleyebilme ve not alabilme imkanına sahip olmasıdır (Denzin ve Lincoln, 2005; Bowen, 2009).

Araştırma Grubu ve Verilerin Toplanması: Araştırma kapsamında Spor Bilimleri Dergisi (1990-2016), Spormetre (2003-2016) ve Niğde Beden Eğitimi ve Spor Bilimleri Dergisi (2007-2016) incelenmiştir. Bu dergilerin belirlenmesindeki temel ölçüt, dergilerin spor bilimleri alanında en az on yıldır süreli akademik yayın yapma şartını sağlamasıdır. Makalelere dergilerin internet sitelerindeki arşiv bölümünden ulaşılmıştır. 1990-2016 tarihleri arasında, toplamda 948 makaleye erişilmiş, bu makalelerin başlıklarına bakılmış, “araştırma amacı” bölümlerinin içeriği incelenmiş 
ve spor psikolojisi, spor sosyolojisi, spor felsefesi, spor yönetimi, rekreasyon, spor tarihi gibi sporda sosyal alanlarda 400 makale belirlenmiştir.

Verilerin Analizi: Sporda sosyal alanlarda yayınlanmış 400 makale, araştırma metodolojileri, araştırma deseni, veri toplama teknikleri ve araştırma alanları başlıkları çerçevesinde kategorik olarak sınıflandırılmıştır. Makalelerde kullanılan araştırma yöntemleri, araştırma desenleri ve veri toplama araçları da makalelerin "yöntem" bölümü incelenerek kategorik olarak ayrıştırılmıştır. Nicel araştırma desenleri, Karasar'ın (2013) sınıflandırmasına göre betimsel tarama, ilişkisel tarama, nedensel-karşlaştırmalı tarama ve deneme olarak belirlenirken; nitel araştırma desenleri ise fenomenoloji, etnografi, durum/vaka çalışması, anlatı ve doküman inceleme gibi kategorilere ayrılarak belirlenmiştir (Skinner, Edwards ve Corbett, 2015). Kuhn'un (2008) bilimsel paradigmalardaki dönüşümlere yönelik sağlıklı bir analiz için öne sürdüğü tarihsellik vurgusu ve diğer çalışma örneklerindeki dönemsel analizlere dayanarak (Culver ve ark., 2012; Quarterman ve ark., 2010; Abeza ve ark., 2015) paradigma gidişatına ve dönüşümüne dair değerlendirmeyi kolaylaştırmak için, üç farklı dönem oluşturulmuş, 1990-1999 yılları arasındaki dönem birinci dönem, 2000-2009 yılları arasındaki dönem ikinci dönem ve 2010-2016 yılları arasındaki dönem de üçüncü dönem olarak sınıflandırılmıştır. İncelenen dergilerden sadece Spor Bilimleri Dergisi’nin birinci dönemde yayın faaliyetleri yürüttüğü görülmekte ve bu, araştırma için bir sınırlılık olarak değerlendirilmektedir. Öte yandan, Açıkada'nın (1993; 1997) 1990'lı yıllardaki spor bilimlerini tariflerken dile getirdiği ekolün ve akademik yapının pozitivist sağlık bilimler yaklaşımlı alanlar üzerine temellendirmesi hususunun, sporda sosyal alanlar için de belirleyici olabileceği düşünülmüştür. O dönemin (1990-1999) sınırlı sayıdaki makaleleri de bu sebeple araştırma kapsamına alınmıştır. İçerik analizine geçmeden önce araştırmacılar tarafından excel programında kategorik birimler oluşturulmuştur (makale yılı, makale başlığı, araştırma alanı, yöntem, desen, veri toplama teknikleri). İçerik analizi sırasında incelenen makaleler, anahtar kelimeler (nicel, nitel, derleme, ölçek, fenomenolojik vb.) ile oluşturulan birimlere kodlanmıştır. Bu süreçte iki araştırmacı tarafından kodlamalar gerçekleştirilmiş; sınıflandırılamayan makaleler üç araştırmacının tekrar incelemesiyle kategorize edilmiştir. Kodlanarak kategorileştirilen veriler, SPSS programına aktarılmış; burada üç araştırmacı kodlara dair hataların tespiti, ortak terminolojinin kullanımı gibi son düzenlemeleri gerçekleştirmiştir. İçerik analizinin sonrasında betimleyici (frekans ve yüzdeler) istatistikler yapılarak veriler analiz edilmiştir. Araştırmanın bulgular bölümündeki paradigma eğilimlerine yönelik değerlendirmeler, araştırmaların bilimsel felsefesindeki (ontolojik, epistemolojik, metodolojik) bütünlüğün ve tutarlllığın esneklik göstermesinin pek mümkün olmadığı yaklaşımından hareketle- makalelerin metodolojik yaklaşımları üzerinden gerçekleştirilmiş̧ir (Sparkes, 2015; Gill, 2011; McGannon ve Smith, 2014).

\section{BULGULAR}

Araştırma kapsamında incelenen sporda sosyal alanlardaki 400 makalenin araştırma yöntemine yönelik eğilimini ortaya koyabilmek için makalelerin araştırma alanlarının dağılımı ile kullanılan araştırma yöntemlerinin, araştırma desenlerinin ve veri toplama araçlarının dağılımı genelden dönemlere doğru gidilerek şekiller ile gösterilmiştir. Öncelikli olarak sporda sosyal alanlar olarak belirlenen alanlarda yapılan çalışmaların dağılımı (Şekil 1), akabinde makalelerde kullanılan araştırma yöntemlerinin hem genel hem dönemsel dağılımları birlikte sunulmuştur (Şekil 2). Yöntemlerin dağılımı verildikten sonra, alandaki disiplinlerde hangi yöntem yaklaşımının daha yaygın olduğunun genel dağılımı verilmiştir (Şekil 3). Genel olarak bakıldığında, araştırma kapsamında öngörülen ve planlanan dönemsel ve sistematik inceleme yaklaşımı, -yöntemlerin yıllar bazındaki eğilim seyrinde gözle görülür herhangi bir değişiklik olmaması sebebiyle- araştırmada sınırlı bir noktada kalmıştır. Yöntem yaklaşımlarında bir geçiş ya da dönüşüm olmamakla birlikte, tercih edilen yöntemler içerisinde hangi trendin oluştuğunu göstermesi açısından dönemlere göre sunulan bilgilerin 
önemli olduğu düşünülmüştür ve makalelerde ele alınan araştırma desenlerinin ve veri toplama tekniklerinin dönemlere göre dağılımı aktarılmıştır (Şekil 4, 5, 6, 7).

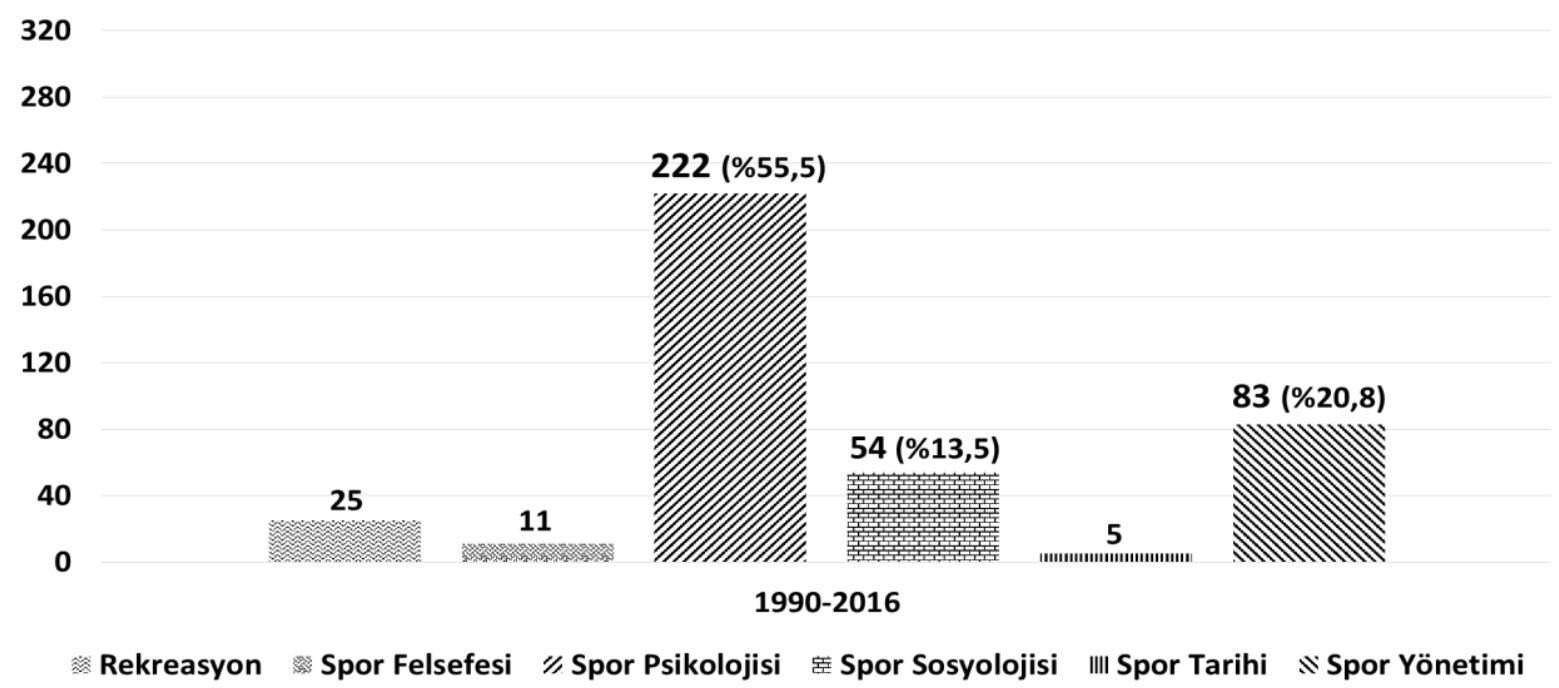

Şekil 1: Sporda sosyal alanlar araştırma alanlarında ele alınan makalelerin dağılımı (1990-2016)

Şekil 1'de gösterilen makalelerin araştırma alanlarına bakıldığında, 400 makale içerisinde, spor psikolojisi (n=222; \%55,5), spor yönetimi $(\mathrm{n}=83 ; \% 20,8)$ ve spor sosyolojisi $(\mathrm{n}=54 ; \% 13,5)$ alanları çalışmaların en sık yapıldığı bilim alanları olarak göze çarpmaktadır.

Derleme $\mathbb{N} 8,8$

Nitel $\quad$ II/ 13,2

Nicel
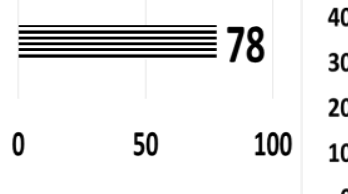

100

90
80

80
70

70

60

50

40

30

10

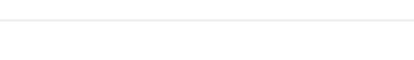
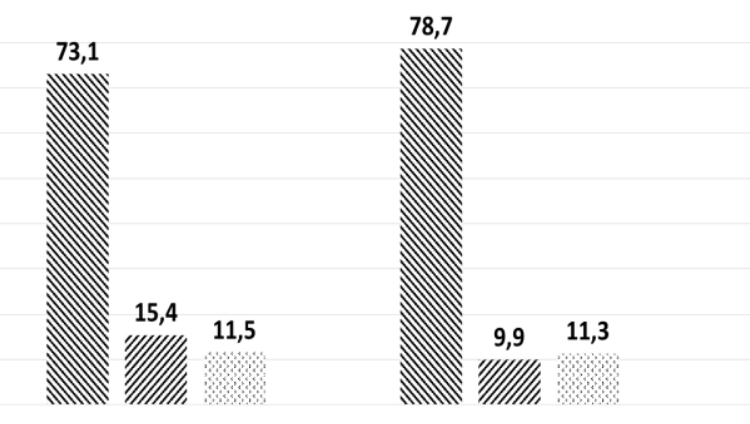

2000-2009

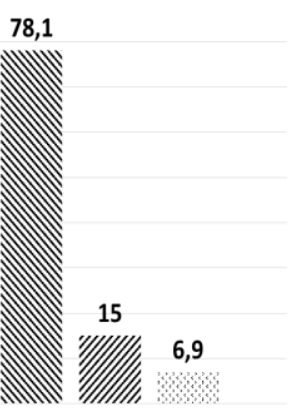

2010-2016

NNicel $\mathscr{\text { Nitel }}$ Derleme

Şekil 2: Makalelerde kullanılan araştırma yöntemlerinin genel ve dönemlere göre dağılımı

Araştırma bulgularına bakıldığında (Şekil 2); toplam 400 makalenin \% 78 'inde ( $\mathrm{n}=312)$ nicel araştırma yöntemleri, $\% 13,2$ 'sinde ( $\mathrm{n}=53)$ nitel araştırma yöntemleri ve \%8,8'inde ( $\mathrm{n}=35)$ ise derleme çalışmalarının kullanıldığı görülmektedir. Dönemler ele alındığında, birinci dönemde yayınlanan 26 makalede \%73,1 (n=19); ikinci dönemde yayınlanan 141 makalede \%78,7 ( $\mathrm{n}=111)$; üçüncü dönemde yayınlanan 233 makalede \%78,1 $(\mathrm{n}=182)$ oranında nicel araştırma kullanıldığı görülmektedir. Nitel yöntemin ise birinci dönemde $\% 15,4(\mathrm{n}=4)$; ikinci dönemde $\% 9,9(\mathrm{n}=14)$; üçüncü dönemde \%15 ( $\mathrm{n}=35)$ oranında kullanıldığı anlaşılmaktadır. 


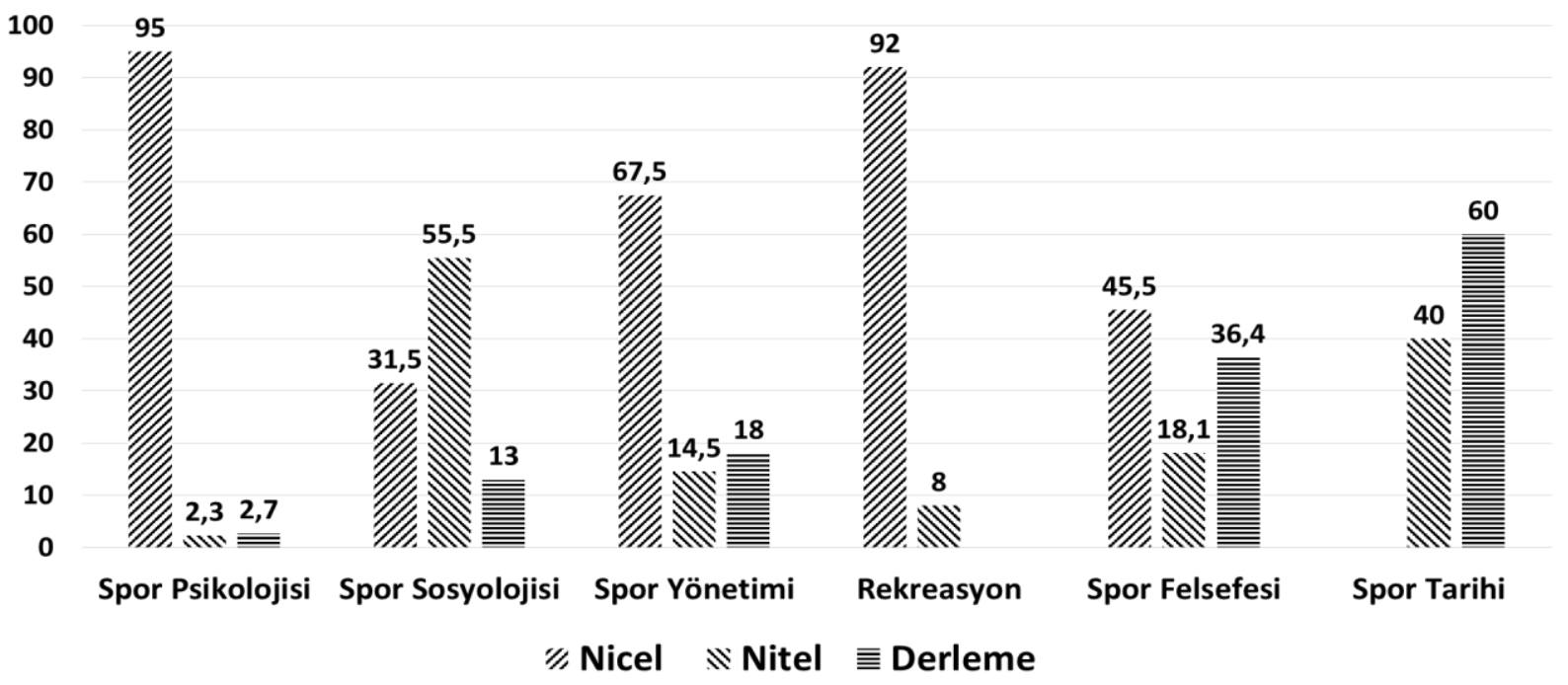

Şekil 3: Araştırma alanlarındaki makalelerde kullanılan araştırma yöntemlerinin genel dağılımı (1990-2016)

Şekil 3'te gösterilen araştırma alanlarında yöntem dağılımına bakıldığında, spor psikolojisi alanında nicel araştırmanın çok yaygın olduğu \%95 $(\mathrm{n}=211)$ görülmektedir. Spor yönetimi alanındaki makalelerin \%67,5’i $(\mathrm{n}=56)$ ve rekreasyon alanındaki makalelerin \%92'si (n=23) de nicel yönteme dayanan çalışmalardır. Spor sosyolojisi alanındaki makalelerde ise \%55,5 (n=30) oranında nitel araştırmaya dayalı çalışmaların olduğu görülmektedir. Bulgulara bakııldığında, toplamda nicel araştırma yöntemiyle yürütülen 312 çalışma (Şekil 2) içerisinde spor psikolojisi alanının 211 (\%68) çalışma ile çok güçlü bir etkisinin olduğu anlaşılmaktadır.

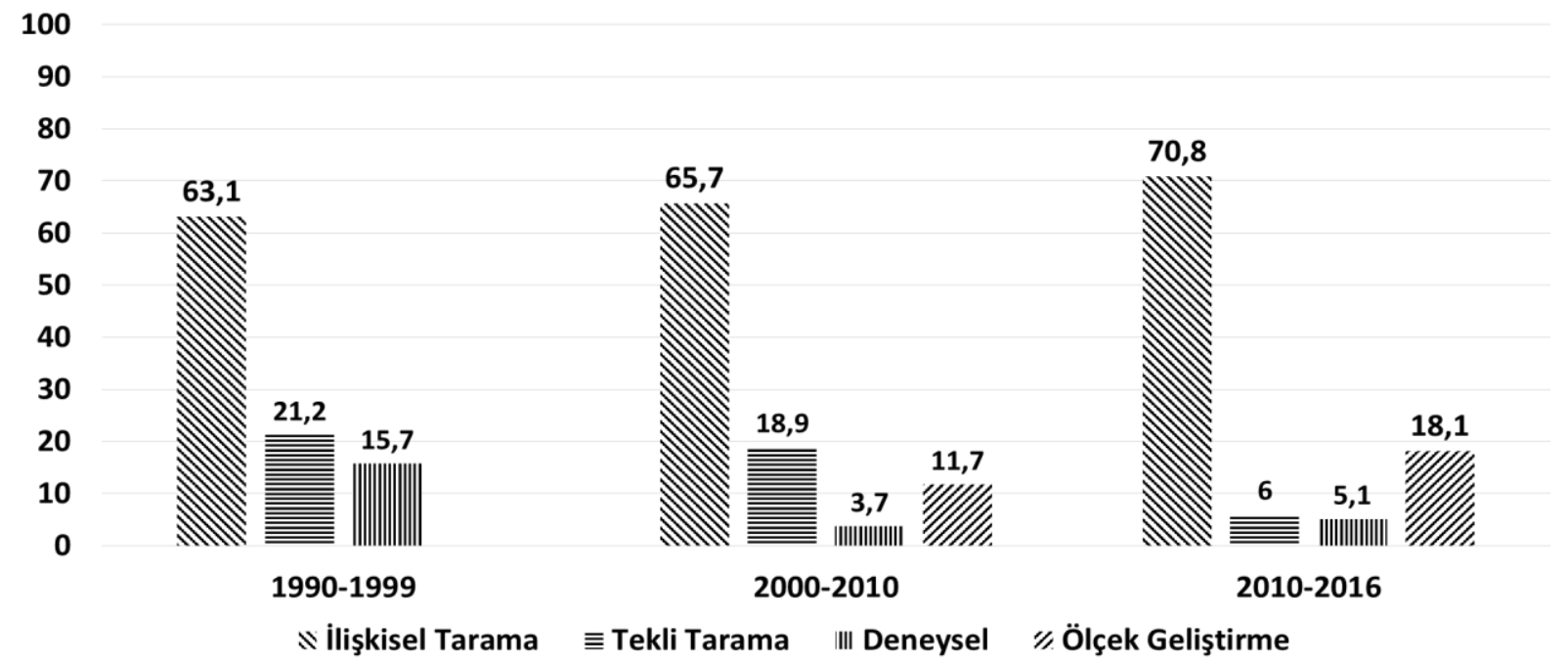

Şekil 4: Makalelerde ele alınan nicel araştırma desenlerinin dönemlere göre dağılımı

Makalelerde kullanılan nicel araştırma desenlerinin dağılımına (Şekil 4) bakıldığında, ilişkisel taramanın üç dönemde de sıklıkla seçildiği, son dönemde de artarak $(\% 70,8)$ kullanıldığı görülmektedir. Tekli tarama desenli çalışmalar son döneme doğru azalırken (\%6); ilk dönemde hiç bulunmayan ölçek geliştirme çalışmaları son döneme doğru en çok tercih edilen ikinci nicel araştırma deseni olmuştur $(\% 18,1)$. Bulgulara bakıldığında, dönemlere göre değişiklik göstermeyen araştırma yaklaşımlarının yanında (Şekil 2), nicel yöntemde betimleyici çalışmalardan ilişkisel ve karşılaştırmalı-nedensel desenlere bir yönelim söz konusudur ve ölçek geliştirme (ve küçük bir artış da olsa deneysel desenli çalışmalar) gibi pozitivist alana yenilik katan, özgün araştırmaların da yükselme trendinde olduğu anlaşılmaktadır. 


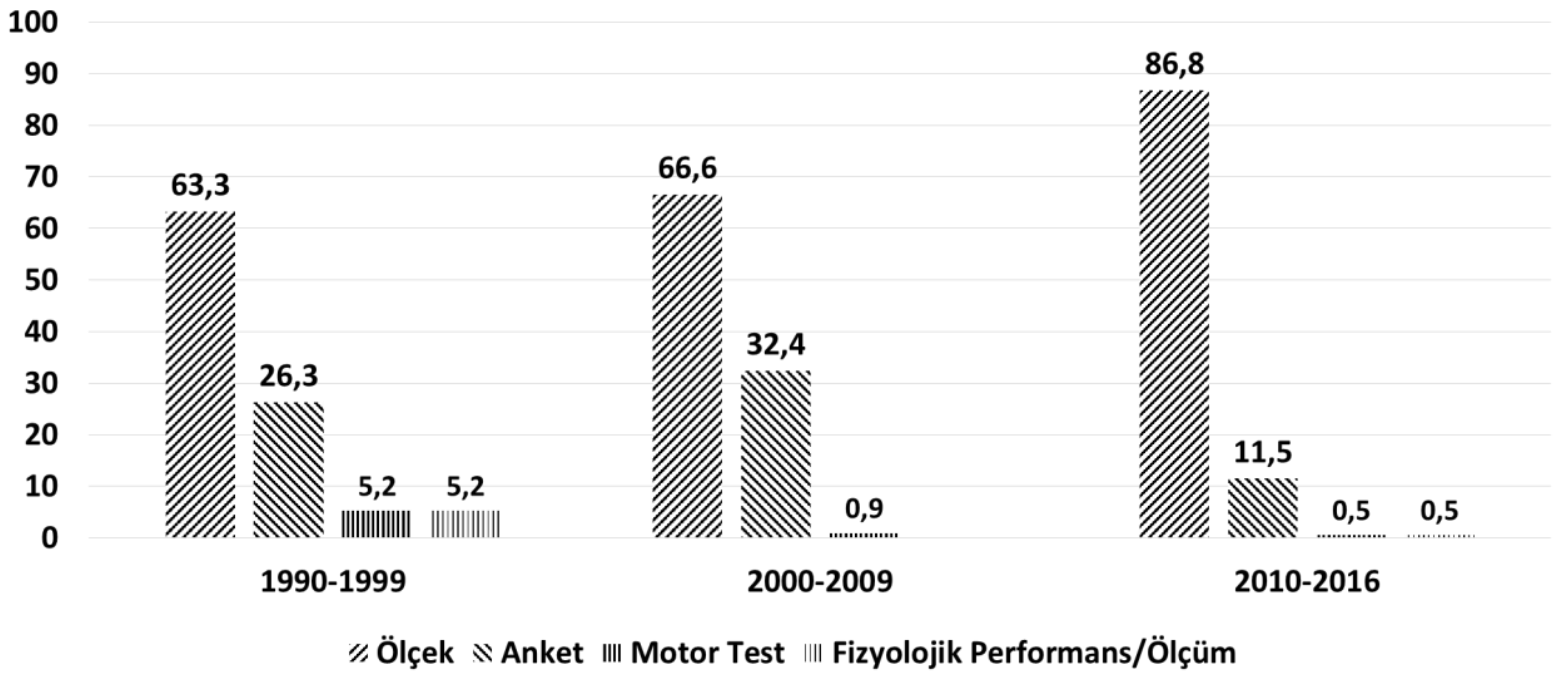

Şekil 5: Makalelerde kullanılan nicel veri toplama tekniklerinin dönemlere göre dağılımı

Makalelerde kullanılan nicel veri toplama tekniklerinin Şekil 5'deki dağılımına bakıldığında, nicel yöntemde ölçek çalışmalarının birinci dönemden üçüncü döneme doğru önemli bir artış gösterdiği (\%63,3'den \%86,8'e), buna paralel olarak anket formlarının son döneme gelindiğinde azaldığı (\%11,5’e) bulunmuştur. Şekil 4’te sunulan ilişkisel tarama ve ölçek geliştirme yaklaşımlı çalışmaların da birlikte son dönemde \%88,9 oranında çalışılıyor oluşu, Şekil 5'te gösterilen veri toplama tekniklerinden ölçek çalışmaları oranı $(86,8)$ ile paralellik göstermektedir.

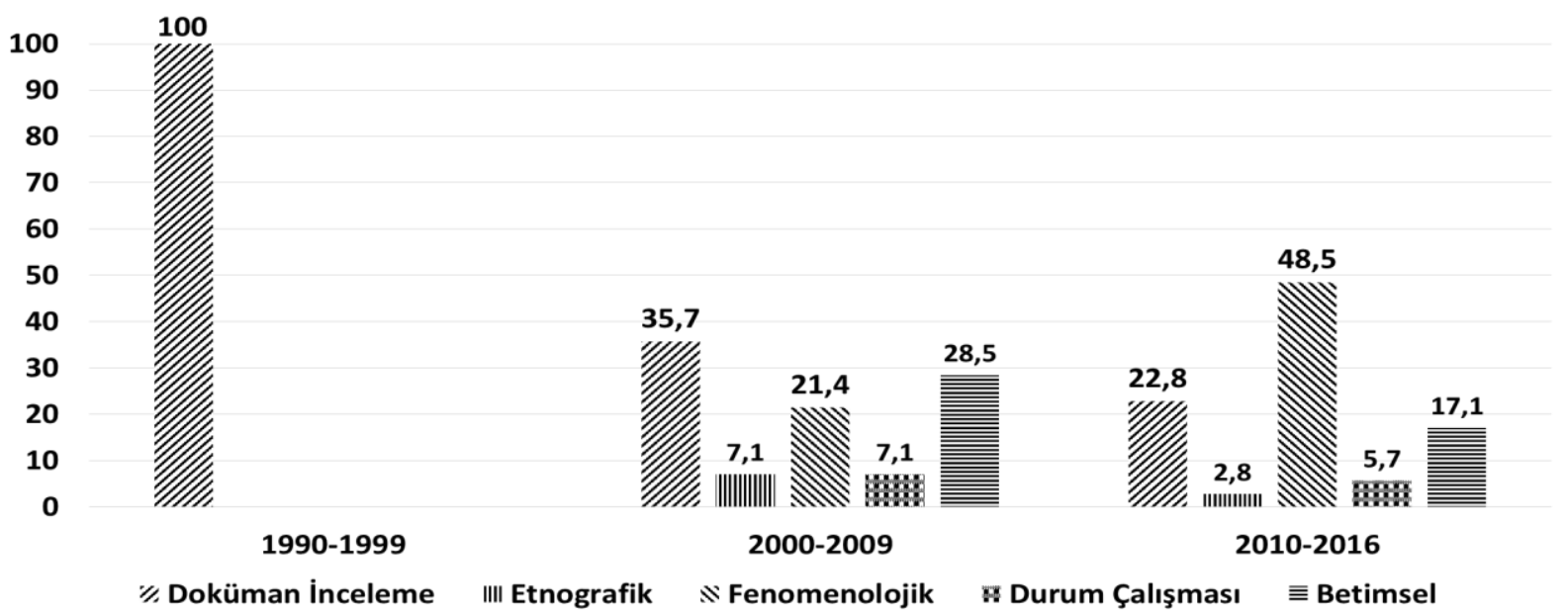

Şekil 6: Makalelerde ele alınan nitel araştırma desenlerinin dönemlere göre dağılımı

Makalelerde kullanılan nitel araştırmalarda (Şekil 6) ilk dönemde sadece doküman inceleme tekniğinin kullanıldığ1 (\%100); son dönemde ise fenomenolojik desenli çalışmaların en çok kullanılan nitel araştırma deseni olduğu (\%48,5) görülmektedir. Öte yandan, betimsel desenli çalışmaların ikinci dönemden son döneme gelindiğinde (\%28,5’ten \% 17,1 'e) azaldığı bulgusuna ulaşılmıştır. Bulgulara bakıldığında, özellikle ikinci dönem itibariyle nitel araştırma yönteminde farklı desen yaklaşımlarının çeşitliliği göze çarpmaktadır. 


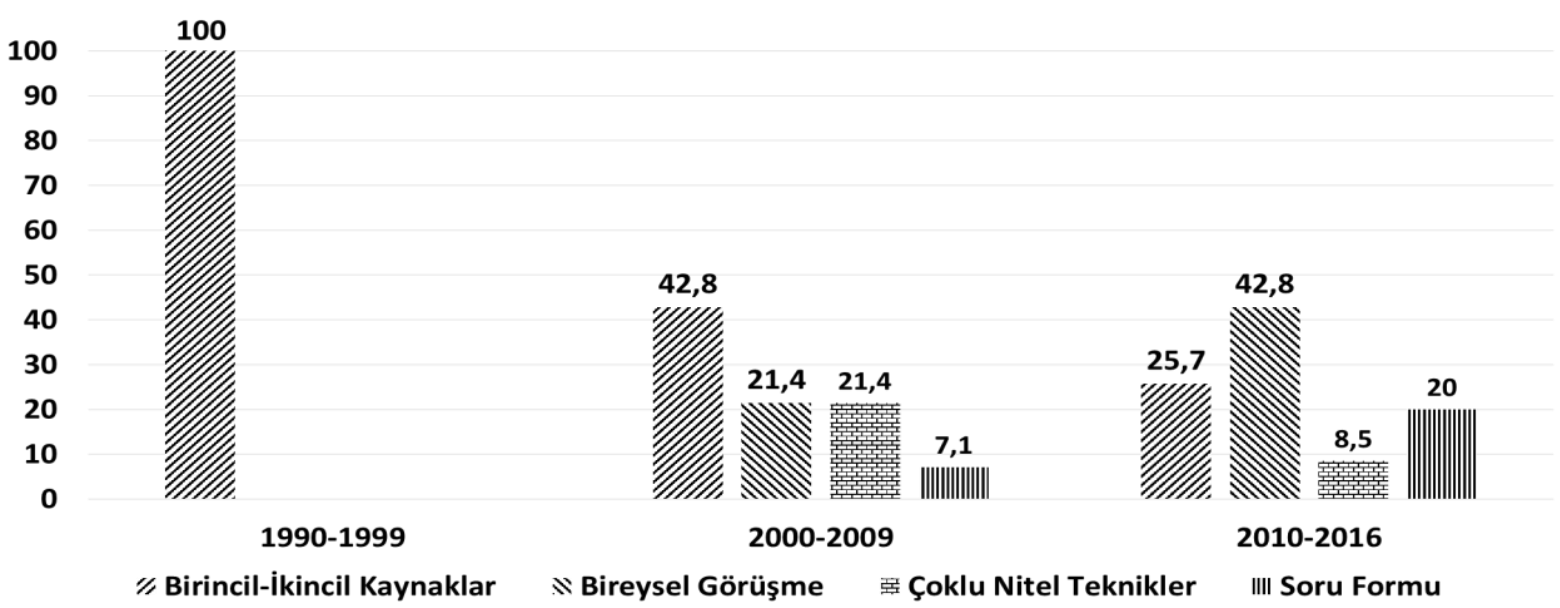

Şekil 7: Makalelerde kullanılan nitel veri toplama tekniklerinin dönemlere göre dağılımı

Makalelerde kullanılan nitel veri toplama tekniklerinin Şekil 7'deki dağılımına bakıldığında, birincil-ikincil kaynak kullanımının son döneme doğru gitgide azaldığ 1 (\%100’den \%25,7’ye); bireysel görüşme tekniğinin ise ikinci dönemden son döneme doğru artış gösterdiği (\%21,4'ten \%42,8'e) anlaşılmaktadır. Açık uçlu soru formlarının kullanıldığı çalışmaların son dönemde \%20 oranında olduğu görülmektedir. Bulgulara bakıldığında, Şekil 6'da olduğu gibi ikinci dönem itibariyle nitel araştırma yönteminin özgün araştırma yaklaşımlı veri toplama tekniklerinin kullanıldığı görülmektedir.

Tablo 1: Sporda Sosyal Alanlardaki Araştırmaların Temalara Göre Dağılımı

\begin{tabular}{lcc}
\hline TEMALAR & n & \% \\
\hline Güdülenme & 46 & 11,5 \\
Benlik & 25 & 6,2 \\
İş-Yaşam Doyumu ve Tükenmişlik & 23 & 5,8 \\
Örgütsel Kavramlar & 19 & 4,8 \\
Kişilik & 16 & 4 \\
Toplumsal Cinsiyet & 14 & 3,5 \\
Kaygı & 13 & 3,3 \\
Spor ve Medya & 12 & 3 \\
Serbest Zaman & 12 & 3 \\
\hline
\end{tabular}

Araştırma başlangıcında bir boyut olarak öngörülmeyen fakat mevcut bulgular çerçevesinde ayrıca inceleme ihtiyacı duyulan başka bir boyut ise sporda sosyal alanlardaki araştırma alanlarının temalara göre dağılımı olmuştur. Alanda \% 78 oranında olan -ve azalmayan bir eğilim ile kullanılan- nicel araştırma yaklaşımının araştırma konularını da belirlediği, Tablo 1'e bakılarak söylenebilir. Çalışmalar arasında sırasıyla en çok ele alınan konuların yansıtıldı̆̆ı Tablo 1 
incelendiğinde, güdülenme ( $\mathrm{n}=46)$, benlik ( $\mathrm{n}=25)$, iş-yaşam doyumu ve tükenmişlik ( $\mathrm{n}=23)$, örgütsel kavramlar $(\mathrm{n}=19)$, kişilik ( $n=16)$, toplumsal cinsiyet $(n=14)$, kaygı $(n=13)$, serbest zaman ve spor-medya ( $n=12$ 'şer) temalarının makalelerde araştırma konusu olarak öne çıktı̆̆ görülmektedir. Özellikle spor psikolojisi ve spor yönetimi alanlarında sıklıkla ölçek çalışmaları ile araştırılan konular olan güdülenme, benlik, kişilik, iş-yaşam doyumu ve tükenmişlik konularının araştırma kapsamında da daha fazla çalışılıyor olması, yöntem ile konu arasındaki ilişkiyi ortaya koymaktadır.

\section{TARTIŞMA}

$\mathrm{Bu}$ çalışmada, alandaki mevcut makalelerin araştırma yöntemlerinin belirlenmesinde araştırmacıların hangi eğilimde/yönelimde olduğunu ortaya koymak amaçlanmıştır. Araştırma bulgularına dayanarak makalelerde ortaya çıkan araştırma yöntemlerinin genel durumu üzerinden, alandaki paradigma yaklaşımının hangi doğrultuda seyrettiğini tartışmak hedeflenmiştir. Araştırma sürecinde, yöntem bölümünde dönemsel ve sistematik bir analiz ile (Kuhn'un da paradigma değişimleri için öne sürdüğü gibi) paradigma gidişatına ve dönüşümüne dair değerlendirmeyi kolaylaştırmak için, üç farklı dönem oluşturma ihtiyacı duyulmuştur. Fakat araştırmanın analizi sürecinde, araştırmalarda dönemsel olarak bir değişim işareti/eğilimi görülmediği için pozitivist yaklaşımın genel olarak hakimiyetini sürdürdüğü kanaatine varılmış, bulguların incelenmesi ve aktarılması sırasında öngörülen dönemsel ve sistematik analiz bu yönüyle sınırlı kalmıştır.

Çalışmanın bulguları ışı̆̆ında, araştırmaların yöntem ve tasarımlarının genel durumuna bakıldığında, paradigmaya dair sporda sosyal alanlarda pozitivist yaklaşımın devam eden bir baskınlığı olduğu söylenebilir. Araştırma kapsamındaki makalelerin metodolojik özellikleri, dolayısıyla sporda sosyal alanlardaki varsayımlar ve gerçeklik anlayışı, paradigma dönüşümüne dair bir eğilimin genel olarak gözükmediğini ortaya koymaktadır.

Sporda sosyal alanlarda fenomenlerin incelenmesi sürecinde nesnellik, dışarıda konumlanma, sayısallaştırma gibi pozitivist kriterleri barındıran nicel araştırma yaklaşımı, araştırma kapsamındaki makalelerde $\% 78$ oranında, baskın bir şekilde yerini korumaktadır. Nicel yöntem yaklaşımlı değerlendirmelerin bu boyutta baskınlığı bireylerin/fenomenlerin sosyal gerçekliğini yüzeyde bırakarak sınırlayabilmektedir. Williams'ın da dile getirdiği "sosyal bilimlerin temel harcı insandır" (Yüce, Eryaman, Şahin ve Koçer, 2014, s. 3'de belirtildiği gibi) ifadesi üzerinden sporda sosyal alanları değerlendirmek, sporun içindeki bireylerin sporun ve spor bilimlerinin en önemli "harcı" olduğunu akılda tutmak gerekir. Sosyal olarak değerlendirilen bir alanda bulguya ulaşmada bilginin ve doğrunun insandan ve onun duygu ve deneyimlerinden bağımsız olamayacağı ilkesi, bilginin gerçekliği, doğruluğu, yaratılması ve inşa edilmesi sürecinde kritik öneme sahiptir (Pisk, 2014; Whaley ve Krane, 2011). Sosyal bilimlerin gerçekliğe dair böyle bir yaklaşımı var iken, araştırmada pozitivist paradigmaya dayanan nicel yöntemin baskınlığının kaynağı olarak birden fazla sebep gösterilebilir. Açıkada'nın (1993; 1997) dile getirdiği gibi, spor bilimleri ekolünün ve kurumsal yapısının hareket ve antrenman, fizyoloji, spor sağlık gibi pozitivist olan sağlık bilimler yaklaşımlı alanlar üzerine temellendirmesi, alanın pozitivist kültürlenmesinin sebeplerinden olabilir. Öte yandan, araştırma kapsamındaki 400 makalenin 222'sini oluşturan spor psikolojisi alanında pozitivist-nicel yaklaşımlı çalışmaların oranının \%95 (211) olması, sporda sosyal alanlardaki pozitivist (nicel) paradigma baskınlığını önemli bir sebebi olarak değerlendirilebilir.

Bu çalışmada, spor psikolojisindeki çalışmaların $\% 95$ 'i; spor yönetimindeki çalışmaların $\% 67,5$ 'i; rekreasyon alanındaki çalışmaların ise \%92'si nicel araştırma yöntemleri ile gerçekleştirilmiştir. Uluslararası spor psikolojisi ve spor yönetimi alanlarında benzer olmasa da yakın sonuçlarla pozitivist hakimiyetin var olduğu yapılan çalışmalarla ortaya konulmuştur. Üç prestijli spor psikolojisi dergisinde 2000-2009 yılları arasında yayımlanan makalelerin \% 71 'i (Culver, 
Gilbert ve Sparkes, 2012); spor yönetimi alanında 2000-2008 yılları arasında yayımlanan makalelerin ise \%71,9'u pozitivist-nicel yaklaşım ile gerçekleştirilmiştir (Quarterman ve ark., 2010). Türkiye'de ise sporda sosyal alanlardaki tezlerin paradigma dönüşümünü irdeleyen çalışmada, pozitivist-nicel yaklaşımın \% 83,4 oranında tezlerde benimsendiği ortaya konmuştur (Elmas ve ark., 2018). Aynı araştırmada spor sosyolojisi alanındaki tezlerin \%69,5 oranında nicel; \% 025 oranında nitel yöntemlerle yazıldığı ortaya konmuşken, araştırmamızda spor sosyolojisi alanındaki makalelere bakıldığında, \%31,5 oranında nicel; \%55,5 oranında nitel yöntemlerin kullanıldığı ve fenomenolojik desenli çalışmaların son dönemde \%48,5 oranında benimsendiği görülmektedir. Spor sosyolojisinin bu dönüşümü, Koca’nın (2017) derleme makalesinde önemle altını çizdiği, uluslararası spor sosyolojisi alanında yeni bir dönemin başlaması, paradigmaların değişmesi ve pozitivist paradigmadan yorumlamacı paradigmaya doğru yeni bir rotanın ortaya çıkması hususlarıyla geriden gelerek de olsa- paralellik göstermektedir.

Ulusal ve uluslararası düzeyde pozitivist kültürlenmeyi içselleştiren fakat harcı insan olan sporda sosyal alanlarda, nicel araştırma desenlerinden ilişkisel taramanın son dönemde \%70; veri toplama tekniklerinden ölçeklerin \%86,8 oranında makalelerde kullanılması, araştırma kapsamındaki makalelerde pozitivist geleneğin sürdürülmesinde önemli rol almaktadır. Benzer şekilde, Elmas ve ark., (2018) tezleri incelediği çalışmada, ilişkisel ve tekli tarama desenlerinin \%76,3; ölçek ve anket araçlarının \%82,3 oranında kullanılması, pozitivizmin hem makalelerde hem tezlerdeki hakimiyetini göstermektedir. Öte yandan, fiziksel aktiviteye katılımın psikolojisine dair 1990-2008 yılları arasında on derginin tarandığı uluslararası çalışmada da ilişkisel/kesitsel ve tekli desenlerin \%70; ölçeklerin \%65 oranında kullanıldığı ortaya konmuştur (Rhodes ve Nasuti, 2011). Bununla birlikte, ölçek geliştirmenin ve son dönemde yapısal eşitlik modellemelerinin çok sık kullanılması (Weiss ve Gill, 2005; Lindahl, Stenling, Lindwall ve Colliander, 2015), uluslararası alanda da pozitivist geleneğin baskınlığını devam ettirmektedir. Bu bağlamda bu çalışmanın sonuçları gerek ulusal gerekse uluslararası alanyazınla benzerlik göstermektedir.

Yukarıdaki farklı çalışma bulguları, genel çerçevede irdelendiğinde,

- fakülte ve enstitülerin programlarında daha çok pozitivist paradigmanın -dolayısıyla nicel yöntemin- ontolojisi, epistemolojisi ve metodolojisine dair ders içeriklerinin olması (Karadağ, 2009; Yüce ve ark., 2014; Koca, 2017),

- danışmanların kendi paradigmatik perspektifleriyle öğrencileri/araştırmacıları alanda niceliksel çalışmaya ve pozitivist yöntembilime yönlendirmesi (Smith ve Brown, 2011; Whaley ve Krane, 2011; Açıkgöz, Elmas ve Aşçı, 2018),

- araştırmaların genellemelere ulaşabilmek için gruplar arasındaki farklılıkları karşılaştıran nomotetik araştırmaya odaklanması ve lisansüstü programlarının sistematik olarak niceliksel analize, sayısal verilere ve \% 5'lik yanılma paylarına göre inşa edilmesi (Latimer, Ginis ve Perrier, 2011; Fazlığulları ve Kurul, 2012; Whaley ve Krane, 2011; Martens, 1987)

gibi kritik süreçler, sporda sosyal alanlarda pozitivist-nicel yaklaşımın baskınlığını güçlendirmektedir.

Morawski’ye (2011) göre pozitivist, doğa(1) bilimin indirgemeci, değer yargısız, ölçmeye ve sayısallaştırmaya dayalı, tarafsız ve "uzak” olmak gibi özellikleri, alanın araştırmacıları arasında konuşulan ortak bir dile dönüştürmüştür. Bu ortak dil, mutabakata varmayı, yayınları bu yolla üretmeyi ve karakteristik bir iletişimi sağlamayı beraberinde getirmektedir. Porter'ın ifadesiyle, bu karakteristik tarzdaki iletişim ve etkileşim, "bilim camiasının belli bir formasyonunu teşvik" etmektedir (Porter, 1992, s. 643). Uluslararası alanyazında ve Türkiye'de sporda sosyal alanlar camiasında teşvik edilen ve araştırmacıların edindiği formasyon, öğrenilen ve kullanılan dil, üretilen yayınların güçlü bir şekilde pozitivist ekolden etkilendiği ifade edilebilir. Spor bilimlerinde -özelde sporda sosyal alanlarda- nicel araştırma baskınlığının konu seçimi üzerindeki etkisi ise başka önemli bir husustur. Bakan'ın yöntemperestlik (Cosgrove ve ark., 2015, s. 20'de belirtildiği 
gibi), Teo'nun yöntembilimcilik (2009) dediği, araştırma konusunun ikincilleştiği, yöntemin öncelikli olduğu bir araştırma pratiğinden kaynaklanan bu yaklaşım, akademik makalelerin planlanmasında araştırmacılar için belirleyici olabilmektedir. Açıkgöz ve ark., (2018) sporda sosyal alanlarda pozitivist-nicel yaklaşımın benimsenmesinin nedenlerini ortaya koymaya dair akademisyenlerin görüşlerini aldığı çalışmada da yöntemin araştırma konusundan öncelikli bir konumda olduğu katılımcı akademisyen tarafından vurgulanmıştır: "Pozitivist metodoloji bir trend olarak halen devam ediyor. Yeni tanıştığım doktora öğrencilerime soruyorum hangi konuyu çalışıyorsunuz diye? Yapısal eşitlik modeli çalışıyorum diyor." Bu yöntembilim(cilik) eğiliminin başlıca sebepleri, "muhafazakar" paradigma yaklaşımı, yöntembilimsel köktencilik, akademik kariyer/promosyon/teşvik basamaklarını daha kolay ve hızlı geçmek, sonuca çabuk ulaşmak, böylece pragmatik bir yol olarak görmek, akademik niteliği, üretkenliği ve verimliliği bu şekilde göstermek şeklinde sıralanmaktadır (Sparkes, 2013; Lincoln ve Cannella, 2004; Smith ve Brown, 2011; Açıkgöz ve ark., 2018). Ayrıca, çağdaş "bilimsel kültürün” kontrol altında tutulmasında yöntembilimsel muhafazakarlık, aynı dili konuşan, konuları aynı perspektifle ele alan ve tek bir yöntembilim çerçevesinde değerlendiren -çevrebiliminde tek bir ürünün yetiştirilmesi anlamına gelen- tekli kültür (monoculture) anlayışını ilk ve en başta gelen ilke olarak addetmektedir (Lincoln ve Cannella, 2004, s. 8).

Sporda sosyal alanlarda pozitivist-nicel baskınlığın yukarıdaki sebepleri dışında değinilmesi gereken başka muhtemel boyutlar ve hususlar mevcuttur. Makalelerin, akademik atamalara, terfilere ve kariyer basamaklarına ulaşmada, akademik yayınlar içerisinde en önemli gerekliliklerin başında geldiği söylenebilir. 21. yüzyıl neoliberal iktisadi paradigmasının nüfusunu gösterdiği kurumlar arasında artık "girişimci" üniversiteler de vardır ve bu paradigma, akademik yayın politikalarında kendini net bir şekilde göstermektedir (Craig ve ark., 2014; Nalbantoğlu, 2009; Davies ve Petersen, 2005). Neoliberal ve bireysel girişim stratejileri oluşturmak, akademik yayınları performans paradigmasına göre yayınlamak, puanlamak, sıralamak, paraya dönüştürmek gibi gerekçeler sebebiyle akademi ticarileşmekte ve neoliberal politikalar akademik kurumlara sirayet etmektedir (Sparkes, 2013; Shore, 2008; Davies ve Bansel, 2010). Özcan ve Çakır'ın (2016, s. 36) "Üniversite-Toplum, Devlet, Piyasa/Sermaye İlişkileri Bağlamında Üniversite Özerkliğì” başlıklı çalışmasında da neoliberal-esnek üretim paradigmasının, üniversitelerde akademik yayın üretiminde ve yükselme/atama süreçlerindeki puanlama kriterlerine sirayet edişine dair "esnek üretimde parça başı ücret sistemine oldukça yakınlık göstermektedir" şeklindeki ifade, üniversitelerin genel görünümünü anlamak açısından kritik öneme sahiptir. Bu durum, akademik özgürlük ilkesinin yönünü araştırma niteliğine bakılmaksızın yeterli sayıda yayın sahibi olmaya doğru çevirmektedir (Sparkes, 2013; Özcan ve Çakır, 2016; Şahin, Tabak ve Tabak, 2017). Bununla birlikte, parça başı ücret sisteminin ve mantı̆̆ının, Türkiye'deki üniversitelerde örtüştüğü akademik teşvik sistemi de akademi mensuplarını ve bilim insanlarının kendilerini, yıllık faaliyet raporlarında ibraz etmek üzere daha fazla yayın yapmaya dayanan bir rekabet ortamının içinde bulmalarına sebep olmaktadır (Özcan ve Çakır, 2016; Demir, Demir ve Özdemir, 2017; Şahin ve ark., 2017). Yayın politikaları, mikro (fakülte), mezo (üniversite, akademik dergiler) ve makro (yükseköğretim kurumu, devlet) düzeyde kurumlarda, pozitivist geleneğin kendini yeniden üretmesini ve güçlendirmesini de beraberinde getirmektedir (Sparkes, 2013, Davies ve Bansel, 2010; Nalbantoğlu, 2009). En yetkili kurumlar, hem bilimsel gerçekliğe ulaşmada hem yayın faaliyetlerinde akademik performans kriterlerine ulaşmada pozitivist yaklaşımı, sayısallaştırmayı ve ölçülebilir k1lmayı temel ilke olarak benimsemektedir (Tourish, 2011; Sparkes, 2013). Tüm bilimsel disiplinler, performatif üretkenliği otoriteler (kurumlar) tarafından kabul gören paradigmalara dayandırmakta, dar kapsamlı parametreler çerçevesinde rekabet girişimini karakterize etmektedir (Learmonth, 2008). Öte yandan, araştırmacılar, yayınlarının kabul alabilmesi için dergilerin baskın ve gelenek halini alan entelektüel ve yöntembilimsel muhafazakarlığını gözeterek yayınlar yapmaya mecbur kalmaktadır (Tourish, 2011; Lincoln ve Cannella, 2004). 


\section{SONUÇ ve ÖNERILER}

Öğretilen formasyon, gelenek, kurumsal ekol, monoculture denilebilecek tek yöntembilimcilik ve neoliberal performans kriteri sayesinde, -Bourdieu'nün (2004) ifadesiyle “akademik sermayenin gücü”nün- daha da genişlediği pozitivist geleneğin karşısında, sosyal gerçekliğin çoklu, çoğulcu, öznel ve derin boyutunu ortaya koymaya çalışmak gibi bir yaklaşımın gelişmesi için, bilimsel muhafazakarlığı, tek gerçekçiliği/yöntembilimciliği ve pozitivizmi aşmış yeni yaklaşımlar gerekmektedir (Bourdieu ve Wacquant, 2012).

Bulgularda da ortaya çıkan (Tablo 1), sporda sosyal alanlardaki popüler araştırma konularından (güdülenme, benlik, kaygı, kişilik, iş doyumu vb.) "gölgede kalan/bırakılan" sosyal gruplara dair çalışma alanlarına (toplumsal cinsiyet, istismar, zorbalık, lgbti, toplumsal sınıf, etnisite, din, siyaset, milliyetçilik vb.) yönelmenin yeni paradigmatik yaklaşımlara ihtiyacı kaçınılmaz kılacağı ifade edilebilir. Böylelikle, alanda yeni paradigmalara yer açılacağını ve sosyal değişim ve dönüşümün daha anlaşılır bir şekilde ortaya çıkacağının altı çizilebilir. Yeni paradigmatik yaklaşımların sporda sosyal alanlardaki soruları ve sorunları daha derinlikli bir şekilde ortaya koyabilme imkanı oluşabilir. Bayraktar'ın (2007) dediği gibi, günümüz insanının dinamik ve değişken doğasını anlamak için, çoğulcu paradigmalar karşısında taraf olmak değil, bütüncül bir yaklaşımla, insana özgü yeni bir metodolojiyi geliştirmek, bugünün bilimsel camiasının temel yaklaşımı ve sorunu olmalıdır.

\section{KAYNAKLAR}

1. Abeza G, O'Reilly N, Dottori M, Séguin B, Nzindukiyimana O. (2015). Mixed methods research in sport marketing. International Journal of Multiple Research Approaches, 9(1), 40-56.

2. Açıada C. (1993). II. Ulusal Eğitim Kurumlarında Beden Eğitimi ve Spor Sempozyumu: Beden eğitiminden spor eğitimine: sporda yeni felsefeler. Milli Eğitim Basımevi, Ankara, Bildiriler; 57-71.

3. Açıkada C. (1997). Türkiye'de spor eğitimi veren kurumların yeniden yapılanması ve hakemli çalışmaların gelişimi. Hacettepe Üniversitesi Spor Bilimleri Dergisi, 8(1), 17-42.

4. Açıkgöz S, Elmas S, Aşçı H. (2018). Akademisyenlerin gözünden sporda sosyal alanlardaki araştırma yöntemi yaklaşımlarının irdelenmesi. Turkiye Klinikleri J Sports Sci, 10(3), 139-49.

5. Applebaum M. (2012). Phenomenological psychological research as science. Journal of Phenomenological Psychology, 43(1), 36-72.

6. Bal H, Pepe K. (2016). Türkiye'de spor bilimleri derneği tarafindan düzenlenen uluslararası spor bilimleri kongrelerinde sunulan bildirilerin içerik analizi açisindan incelenmesi. Beden Egitimi ve Spor Bilimleri Dergisi, 10 (3), 443-452.

7. Bayraktar F. (2007). Niceliksel - niteliksel araştırma yöntemlerindeki çatallaşma ve çatallaşmayı uzlaşmaya dönüştüren örnek çalışmalar, Türk Psikoloji Bülteni, 13(40), 1-7.

8. Bourdieu P. (2004). Science of Science and Reflexivity. Polity Press.

9. Bourdieu P, Wacquant L. (2012). Düşünümsel Bir Antropoloji İçin Cevaplar. (N Ökten Çev.). (6. Basım). İstanbul: İletişim Yayınları

10. Bowen GA. (2009). Document analysis as a qualitative research method. Qualitative Research Journal, 9(2), 27-40.

11. Cosgrove L, McHugh M. (2008) A post-Newtonian, postmodern approach to science: innovative methods in social action research. (S.N. HesseBiber, P.L. Leavy, Eds.) Handbook of Emergent Methods. s. 73-85. New York: Guilford Publications.

12. Cosgrove L, Wheeler EE, and Kosterina E. (2015). Quantitative methods: Science means and ends. (Ian Parker, Ed.) Handbook of Critical Psychology. s. 15-23. Routledge: Handbooks Online.

13. Coşkun S, Coşkun S. (2015). Performansa dayalı ücret uygulamaları hakkında öğretmenlerin görüşleri: Kahramanmaraş ilinde ampirik bir çalışma. Yönetim ve Ekonomi Araştırmaları Dergisi, 13(3), 56-78.

14. Craig R, Amernic J, Tourish D. (2014). Perverse audit culture and accountability of the modern public university. Financial Accountability \& Management, 30(1), 1-24.

15. Culver DM, Gilbert W, Sparkes A. (2012). Qualitative research in sport psychology journals: The next decade 2000-2009 and beyond. The Sport Psychologist, 26(2), 261-281.

16. Davies B, Petersen EB. (2005). Intellectual workers (un) doing neoliberal discourse. International Journal of Critical Psychology, 13(1), 32-54.

17. Davies B, Bansel P. (2010). Governmentality and academic work: Shaping the hearts and minds of academic workers. Journal of Curriculum Theorizing, 26(3), 5-20. 
18. Demir E, Demir CG, Özdemir MÇ. (2017). Akademik yükseltme ve atama sürecine yönelik öğretim üyesi görüşleri. Journal of Higher Education \& Science/Yüksekögretim ve Bilim Dergisi, 7(1), 12-23.

19. Denzin NK, Lincoln YS. (2005). The Sage Handbook of Qualitative Research. Thousand Oaks, California: Sage.

20. Dikeçligil B. (2010). Bilimsel paradigmaların oluşumunda ve dönüşümünde sosyolojik bağlam. Toplum Bilimleri Dergisi, 4(7), 53-62.

21. Elmas S, Açıkgöz S, Aş̧̧ı H. (2018). Sporda sosyal alanlarda yapılan lisansüstü tezlerde araştırma paradigmalarının incelenmesi. Spor Bilimleri Dergisi, 29(2), 53-66.

22. Fazlığulları O, Kurul N. (2012). Türkiyedeki eğitim bilimleri doktora tezlerinin özellikleri, Mehmet Akif Ersoy Üniversitesi Eğitim Fakültesi Dergisi, 12(24), 43-75.

23. Fryer D, \& Fox R. (2015). Community psychology: Subjectivity, power, collectivity. (Ian Parker, Ed.) Handbook of Critical Psychology. s. 145-154. Routledge: Handbooks Online.

24. Gau LS. (2013). Trends and topics in sports research in the social science citation index from 1993 to 2008. Perceptual and motor skills, 116(1), $305-314$

25. Giacobbi PR, Poczwardowski A, Hager P. (2005). A pragmatic research philosophy for sport and exercise psychology. The Sport Psychologist, 19(1), 18-31.

26. Gill DL. (2011). Beyond the qualitative-quantitative dichotomy: notes from a non-qualitative researcher, Qualitative Research in Sport, Exercise and Health, 3(3), 305-312.

27. Giorgi A. (2012). The descriptive phenomenological psychological method. Journal of Phenomenological Psychology, 43(1), 3-12.

28. Karadağ E. (2009). Türkiye'de Eğitim Bilimleri Alanında Yapılmış Doktora Tezlerinin Tematik ve Metodolojik Açıdan İncelenmesi: Bir Durum Çalışması. Yayınlanmamış Doktora Tezi. Marmara Üniversitesi. Eğitim Bilimleri Enstitüsü.

29. Karasar N. (2013). Bilimsel Araştırma Yöntemleri. (25. Bask1), Nobel Yayınevi, Ankara.

30. Koca C. (2017). Spor bilimlerinde nitel araştırma yaklaşımı. Spor Bilimleri Dergisi, 28(1), 30-48.

31. Kuhn TS. (2008). Bilimsel Devrimlerin Yapısı. (N Kuyaş Çev.). (8. Baskı). İstanbul: Kırmızı Yayınları.

32. Kümbetoğlu B. (2005). Sosyolojide ve Antropolojide Niteliksel Yöntem ve Araştırma. İstanbul: Bağlam Yayıncılık.

33. Latimer AE, Martin-Ginis KA, Perrier MJ. (2011). The story behind the numbers: a tale of three quantitative researchers' foray into qualitative research territory. Qualitative Research in Sport, Exercise and Health, 3(3), 278-284.

34. Learmonth M. (2008). Speaking out: evidence-based management: a backlash against pluralism in organizational studies?. Organization, 15(2), 283-291.

35. Lincoln YS, Cannella GS. (2004). Dangerous discourses: Methodological conservatism and governmental regimes of truth. Qualitative inquiry, $10(1), 5-14$.

36. Lindahl J, Stenling A, Lindwall M, Colliander C. (2015). Trends and knowledge base in sport and exercise psychology research: a bibliometric review study. International Review of Sport and Exercise Psychology, 8(1), 71-94.

37. Maguire J. (Ed.). (2013). Social Sciences in Sport. Human Kinetics.

38. Martens R. (1987). Science, knowledge, and sport psychology. The Sport Psychologist, 1(1), 29-55.

39. Mattos A. (2015). Feminist psychology: Researches, interventions, challenges. (Ian Parker, Ed.) Handbook of Critical Psychology. s. $329-338$. Routledge: Handbooks Online.

40. McDonald MG, Birrell S. (1999). Reading sport critically: A methodology for interrogating power. Sociology of Sport Journal, 16(4), 283-300.

41. McGannon KR, Smith B. (2015). Centralizing culture in cultural sport psychology research: The potential of narrative inquiry and discursive psychology. Psychology of Sport and Exercise, 17, 79-87.

42. Morawski, J. (2011). Our debates: Finding, fixing, and enacting reality. Theory \& Psychology, 21(2), $260-274$.

43. Nalbantoğlu, HÜ. (2009). Arayışlar: Bilim, Kültür, Üniversit., İletişim Yayınları, İstanbul

44. O'neill P. (2002). Tectonic change: The qualitative paradigm in psychology. Canadian Psychology, 43(3), $190-194$.

45. Özcan D, Çakır H. (2016). Üniversite-Toplum, devlet, piyasa/sermaye ilişkileri bağlamında üniversite özerkliği. Journal of Higher Education \& Science/Yüksekögretim ve Bilim Dergisi, 6(1), 31-40.

46. Öztürk AT. (2010). İnsan kaynakları yönetiminde performansa dayalı ücret ve teşvik sistemi. Organizasyon ve Yönetim Bilimleri Dergisi, 2(2), $1-10$.

47. Pisk J. (2014). Sport science: ontological and methodological considerations. Physical Culture and Sport Studies and Research, 61(1), 5-14.

48. Porter, TM. (1992). Quantification and the accounting ideal in science. Social Studies of Science, 22(4), 633-651.

49. Rhodes RE, Nasuti G. (2011). Trends and changes in research on the psychology of physical activity across 20years: A quantitative analysis of 10 journals. Preventive Medicine, 53(1), 17-23.

50. Quarterman J, Hwang JY, Han K,. Pitts BG, Jackson EN, Ahn T. (2010). 2010 Research Consortium Conference of the AAHPERD Convention: A content analysis of the international journal of sport management. Indianapolis, USA

51. Shore C. (2008). Audit culture and illiberal governance: Universities and the politics of accountability. Anthropological Theory, 8(3), $278-298$. 
52. Skinner J, Edwards A, Corbett B. (2015). Research Methods for Sport Management. Routledge.

53. Smith B, Brown D. (2011). Editorial. Qualitative Research in Sport, Exercise and Health, 3(3), 263-265.

54. Sparkes AC. (2013). Qualitative research in sport, exercise and health in the era of neoliberalism, audit and new public management: Understanding the conditions for the (im) possibilities of a new paradigm dialogue. Qualitative Research in Sport, Exercise and Health, 5(3), 440-459.

55. Sparkes AC. (2015). Developing mixed methods research in sport and exercise psychology: Critical reflections on five points of controversy. Psychology of Sport and Exercise, 16, 49-59.

56. Şahin F, Tabak BY, Tabak H. (2017). Motivasyon kuramları bağlamında akademik teşvik ödeneği uygulamasının değerlendirilmesi. Journal of Higher Education \& Science/Yüksekögretim ve Bilim Dergisi, 7(2), 403-410.

57. Teo, T. (2009) Teo, T. (2009). Philosophical concerns in critical psychology. (D. Fox, I. Prilleltensky, \& S. Austin, Eds.) Critical Psychology: An Introduction. s. 36-53. Thousand Oaks, CA, : Sage Publications Ltd.

58. Critical Psychology: An Introduction. Thousand Oaks, CA: Sage Publications.

59. Tourish D. (2011). Leading questions: Journal rankings, academic freedom and performativity: What is, or should be, the future of leadership?. Leadership, 7(3), 367-381.

60. Weiss MR, Gill DL. (2005). What goes around comes around: re-emerging themes in sport and exercise psychology. Research Quarterly for Exercise and Sport, 76(2), 71-87.

61. Whaley DE, Krane V. (2011). Now that we all agree, let's talk epistemology: a commentary on the invited articles, Qualitative Research in Sport, Exercise and Health, 3(3), 394-403.

62. Yüce K, Eryaman MY, Şahin A, Koçer Ö. (2014). Sosyal bilimlerde paradigma dönüşümü ve türkiye'de uygulamalı dilbilimi alanında nitel araştırma. Eğitim ve Bilim, 39(171), 1-12 